\title{
Prevalence of sickle cell disorders and malaria infection in children aged 1-12 years in the Volta Region, Ghana: a community-based study
}

Mavis Oppong ${ }^{1}$, Helena Lamptey ${ }^{2}$, Eric Kyei-Baafour ${ }^{2}$, Belinda Aculley², Ebenezer Addo Ofori ${ }^{2}$, Bernard Tornyigah², Margaret Kweku ${ }^{1}$ and Michael F. Ofori ${ }^{2^{*}}$

\begin{abstract}
Background: Alterations in the structure of haemoglobin $(\mathrm{Hb})$ are usually brought about by point mutations affecting one or, in some cases, two codons encoding amino acids of the globin chains. One in three Ghanaians are said to have sickle cell disorders, whereas malaria continues to be one of the leading causes of mortality among children. This study determined the prevalence of sickle cell disorders and malaria infection among children aged 1-12 years in the Volta Region.

Methods: This was a community-based cross-sectional survey that involved 938 children aged 1-12 years selected from three districts, one each from the 3 geographical zones of the Volta Region using a multistage sampling method. Demographic information was collected using a standard questionnaire and anthropometric indices were measured. Isoelectric focusing (IEF) electrophoresis was used to determine the Hb genotypes and sub-microscopic parasites were determined by PCR.

Results: The prevalence of sickling screening positive was $16.0 \%$ with an overall prevalence of sickle cell disorders being 2.0\%. Among the individual genotypes making up the sickle cell disorders, genotype HbSF was the highest (0.9\% as compared to $0.2 \%$; HbSS, 0.6\%; HbSC and 0.3\%; HbSCF). Microscopic Plasmodium falciparum parasitaemia was detected among $5.5 \%$ of the children and $14.2 \%$ sub-microscopic prevalence by PCR. Children with sickle cell disorders were more likely to have sub-microscopic parasitaemia ( $A O R=5.5195 \% \mathrm{Cl}(2.15,14.10), p<0.001)$ as well as anaemia ( $A O R=3.0395 \% \mathrm{Cl}(1.04,8.82), p=0.042)$, compared to those with normal genotypes. There was no significant difference observed between sickle cell disorders and growth and development of the children screened.

Conclusions: Sickle cell disorders were significantly associated with sub-microscopic parasitaemia as well as anaemia in this study. Establishment of sickle cell clinics in the district and regional hospitals will help in the management of children with the disorder and also generate a national database on sickle cell disorders. National neonatal screening policies must also be put in place to help in early detection and management of these disorders.
\end{abstract}

Keywords: Sickle cell disorders, Plasmodium falciparum, Malaria, Children, Volta region, Ghana

*Correspondence: Mofori@noguchi.ug.edu.gh

2 Department of Immunology, Noguchi Memorial Institute for Medical Research, College of Health Sciences, University of Ghana, Accra, Ghana

Full list of author information is available at the end of the article

\section{Background}

Sickle-cell disorders are types of haemoglobin disorders, which occur due to mutations in one of the globin subunits of haemoglobin $(\mathrm{Hb})$, resulting in a change in amino acid sequence [1]. Normal adult haemoglobin

(c) The Author(s) 2020. This article is licensed under a Creative Commons Attribution 4.0 International License, which permits use, sharing, adaptation, distribution and reproduction in any medium or format, as long as you give appropriate credit to the original author(s) and the source, provide a link to the Creative Commons licence, and indicate if changes were made. The images or other third party material in this article are included in the article's Creative Commons licence, unless indicated otherwise in a credit line to the material. If material is not included in the article's Creative Commons licence and your intended use is not permitted by statutory regulation or exceeds the permitted use, you will need to obtain permission directly from the copyright holder. To view a copy of this licence, visit http://creativeco mmons.org/licenses/by/4.0/. The Creative Commons Public Domain Dedication waiver (http://creativecommons.org/publicdomain/ zero/1.0/) applies to the data made available in this article, unless otherwise stated in a credit line to the data. 
( $\mathrm{HbA})$, consists of a combination of $2 \beta$-globin and 2 $\alpha$-globin chains with a haem [2]. Examples of haemoglobin genotypes considered as sickle cell disorders are sickle cell anaemia/disease (SCA/SCD) (HbSS), sickle cell trait (HbAS), HbSC disease, sickle $\beta$-thalassemia disease $(\mathrm{S} / \beta$ thal), $\mathrm{HbS}$ with other $\mathrm{Hb}$ variants (like $\mathrm{D}$, $\mathrm{O}$-Arab etc.) and $\mathrm{HbS} /$ Hereditary persistence of fetal haemoglobin HbS/HPFH (HbSF) $[1,3]$.

The sickle haemoglobin $(\mathrm{HbS})$ in sickle cell disorders results from an amino acid substitution at the sixth residue of the $\beta$-globin subunit; valine for glutamic acid $[1,4]$. The resulting valine is a hydrophobic amino acid unlike the glutamic acid, which is hydrophilic. This hydrophobic amino acid interacts with another haemoglobin leading to the polymerization of deoxygenated red blood cell, causing the shape of the normal haemoglobin to be distorted into sickle shaped, which results in the obstruction or occlusion of the blood vessels $[5,6]$. Manifestations of sickle cell disease in children include, but not limited to, anaemia, poor growth, fatigue and jaundice [7]. Some common complications include frequent attacks of severe pain also called crises, acute severe anaemia, malaria and other infections, stroke (especially among children), acute lung damage, development of cerebrovascular disease and cognitive impairment $[7,8]$.

Sickle cell disease patients in the developed world account for only $10 \%$ of the world's SCD patient population [9]. However, it is known that the disorder follows a more severe clinical course in Africa than in other parts of the world, and that infectious diseases (like malaria) have a role in causing this increased severity [8]. In 2010, an estimated $79 \%$ of newborns with SCD occurred in sub-Saharan Africa and this proportion is expected to increase to $88 \%$ by 2050 [10].

Plasmodium falciparum malaria results in high morbidity and mortality among first time primigravid women and children under 5 in sub-Saharan Africa, hence, still remains a major public health problem. It has been hypothesized that, these sickle cell disorders, have been naturally selected to confer protection against severe forms of malaria in endemic areas [11, 12].

Studies have shown that individuals with HbSS or HbAS variants have reduced risk of high-density parasitaemia. However, HbSS individuals have an increased mortality rate if they become parasitaemic compared to $\operatorname{HbAS}[9,13]$. Those with HbAS have been shown to have asymptomatic infections and are best described as malaria-protective $[8,14,15]$. The mechanisms proposed involves reduced parasite growth in infected erythrocytes, decreased cytoadherence of parasitized RBCs to endothelium, which enhances the removal of parasitized cells by the immune system [16].
HbSC disease is associated with significant clinical manifestations, but milder than those of HbSS $[1,8]$. Individuals with $\mathrm{HbSC}$ disease have a higher mean $\mathrm{Hb}$ than those with $\mathrm{HbSS}$ [17]. Although $\mathrm{HbSF}$ has $~ 70 \% \mathrm{HbS}$ and $\sim 30 \% \mathrm{HbF}$, it is clinically asymptomatic compared to HbSS because every RBC contains $\sim 30 \% \mathrm{HbF}$. Since $\mathrm{HbF}$ does not participate at all in polymer formation, a situation where hydrophobic amino acid interacts with another haemoglobin to aggregate into large polymers, thus prevents sickling of all RBCs under physiological conditions [1]. HbSS has more severe clinical manifestations, thus it is of great public health concern, compared to HbSC and HbSF that has mild clinical symptoms [10].

In Ghana, studies indicate that $2 \%$ of Ghanaian newborns are affected by SCD annually; one in three Ghanaians has HbAS, HbSS or HbSC genotype $[18,19]$. Newborn screening with early diagnosis and comprehensive care has been shown to improve child survival since the sickle cell disease has a high mortality rate in the first few years of life [18, 20,21]. A previous study in one of the Municipalities in the Volta Region of Ghana discovered a considerable prevalence of sickle cell disorders among children [22] and malaria prevalence of $28 \%$ in this region. This study determined the prevalence of sickle cell disorders among children aged 1-12 years, and also assessed the influence of these disorders on malaria infection, anaemia and the growth and development of children.

\section{Methods}

\section{Study sites and population}

The study was conducted in 3 out of 25 districts of the Volta region (one from each of the 3 ecological zones). The selected districts were Keta Municipality (Southern zone), Hohoe Municipality (Middle zone) and Krachi West District (Northern zone) (Fig. 1).

Keta Municipality has a population of approximately 147,618 with more than half (53.3\%) living in urban areas. It has annual rainfall of less than $1000 \mathrm{~mm}$, being one of the driest along the coast of Ghana. The population of Hohoe Municipality is about 167,016 with 52.6\% of this populace living in urban areas. The annual rainfall is $1592 \mathrm{~mm}$. Krachi West District has a population of 49,417 with $81.8 \%$ of the natives living in rural areas. A map of the region indicating the sites is shown (Fig. 1).

Malaria transmission in the Volta region reflect the national transmission pattern and differs among the three major bioecological zones in Ghana. Keta is in the coastal scrub zone, Hohoe within the middle belt with forest transition or semi-deciduous zone and Krachi representing the northern Guinea savanna zone. Transmission is low in Keta, intermediate in Hohoe and Krachi has high transmission [23]. 


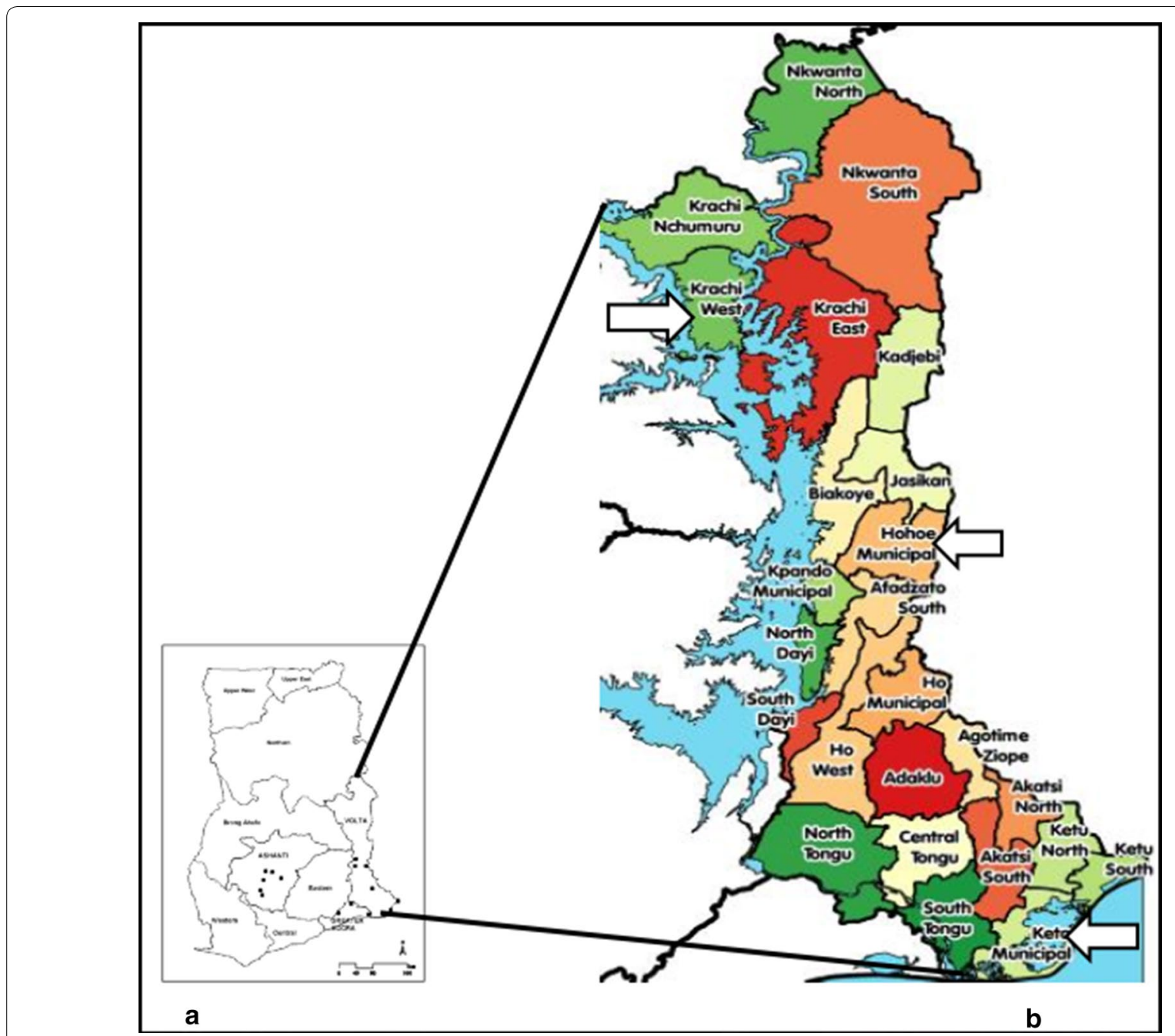

Fig. 1 Map of Ghana (a) showing the Volta Region with all its districts (b). The Study sites (Keta Municipality, Hohoe Municipality and the Krachi West district) are shown by the white arrows

The study was conducted in December 2018, and the study population consisted of children aged 1-12 years living in selected communities within the 3 selected districts. Inclusion criteria were children within the stated years whose parents/guardians gave consent to be part of the study and were residents in the study area. Those excluded were children who were seriously ill and requiring medical care, and those with major congenital defects as well as those whose parents/guardians did not consent to be part of the study.

\section{Study design and sampling}

Cross-sectional community-based surveys were used. A multi-staged sampling was used in which the list of all the districts in each zone was obtained and one district randomly selected from each zone. Three communities were randomly selected from each of the 3 selected districts giving a total of nine communities. However, during the survey, one community did not confirm their willingness to participate in the study, hence 8 communities out of 9 were visited. Interviews were conducted and recorded using semi-structured questionnaires to collect background demographic information of children. In each of the selected communities, all children who were eligible and their parents/guardians gave consent, were enrolled. Anthropological measurements and biological samples were collected from 938 participants.

\section{Data collection and sampling}

Parents/guardians of the children were interviewed using a pre-tested semi-structured questionnaire. Finger prick dried blood spots (DBS) were collected on Whatman 
No.5 filter paper (GE Healthcare, England), for Hb genotyping and PCR. The filter paper blots were air-dried and stored with desiccant at $4^{\circ} \mathrm{C}$ until ready to be used. Some blood drops were also collected on two frosted slides, one for malaria microscopy (thick and thin films) and the other for sickling screening test.

\section{Anthropometric and axillary temperature measurement}

Height was measured using a non-stretchable tape to the nearest $1 \mathrm{~cm}$ according to World Health Organization (WHO) standard. Weight measurement was taken with minimal clothing and without shoes, on a weighing scale with the zero-error corrected before each measurement. Mid Upper Arm Circumference (MUAC) was measured to the nearest $1 \mathrm{~cm}$ using a non-stretchable tape. The growth and body composition of the study population was assessed using the Z-scores of the anthropometric indices of height-for-age (HAZ), weight-for-age (WAZ) and body mass index-for-age (BAZ). The WHO Anthroplus Software was used for the conversion to enable comparison of the study participants to a reference population [24]. Since standing height was taken for all children due to lack of the appropriate equipment, those less than 24 months (who were supposed to be measured in recumbent position) had $0.7 \mathrm{~cm}$ added to their height by the software, to derive an estimated length. All Z-scores which were outside the WHO flags, thus, WAZ -6 to +5 ; $\mathrm{HAZ}-6$ to +6 ; and $\mathrm{BAZ}-5$ to +5 were excluded from the data set. Axillary temperature was measured using a non-contact infrared thermometer (UNIONCARE, Model: IT-122).

\section{Clinical classification}

According to the study protocol, fever was defined as an axillary temperature of $\geq 37.5^{\circ} \mathrm{C}$. Stunting was defined as $\mathrm{HAZ}<-2 \mathrm{SD}$, underweight as $\mathrm{WAZ}<-2 \mathrm{SD}$, thinness as $\mathrm{BAZ}<-2 \mathrm{SD}$, overweight as $\mathrm{BAZ}>+1 \mathrm{SD}$ and obesity as $\mathrm{BAZ}>+2 \mathrm{SD}$ (24). Participants who were stunted, underweight, obese and thin were all classified as malnourished. Operational definition for parasitaemia was microscopy positive and that for clinical malaria was any parasitaemia plus fever. Anaemia was classified using the WHO Vitamin and Mineral Nutrition Information System [25]. The classification of $\mathrm{Hb}$ disorders were grouped into normal (HbAA), Sickle cell disorders ((HbSS, HbSC, $\mathrm{HbSF}$ and $\mathrm{HbSCF})$, Sickle cell trait (HbAS) and "other $\mathrm{Hb}$ disorders" (HbAC, HbAF, HbCC and HbACF) as shown in the supplementary (Additional file 1: Table S1). In this study, sickle cell trait was grouped separately from the other sickle cell disorders to ascertain their individual impact on anaemia and malaria.

\section{Haemoglobin level determination}

A drop of finger prick blood was used to determine the haemoglobin level photometrically using a portable haemoglobin analyser (Hemocue, Sweden). Haemoglobin levels were classified using the WHO Vitamin and Mineral Nutrition Information System [25] with slight modifications; all the three different classifications of Anaemia; "Mild", "Moderate" and "Severe", were merged under one group, "Anaemia".

\section{Sickling screening test and haemoglobin genotyping}

Study participants were screened for sickling status using the sodium metabisulfite method (Sigma Aldrich, USA). Haemoglobin genotyping was performed using Isoelectric focusing (IEF) electrophoresis method with the Multiphor II electrophoresis unit (GE Healthcare, Little Chalfont, England). Controls and samples were run at a constant power of $26 \mathrm{~W}$ (1200 V and $300 \mathrm{~mA})$ for about $1 \mathrm{~h}, 30 \mathrm{~min}$. The gel plates were fixed with $10 \%$ trichloroacetic acid and then placed in a distilled water washing tray on a racking shaker for $12 \mathrm{~min}$. After 5 cycles of washing, the gel was placed in a $60 \mathrm{oC}$ oven to dry. The bands formed by individual haemoglobin were then compared to those of the respective controls and recorded.

\section{Parasitaemia by microscopy}

Both thick and thin blood smears were prepared on a single frosted slide, air dried and stained with $10 \%$ Giemsa (thin film fixed with methanol) for detection of both asexual and sexual stage parasites by microscopy under oil immersion $(100 \times$ magnification). Parasite densities were assessed by counting 200 leucocytes and were later converted to number of parasites per microlitre of blood by assuming a standard leucocyte count of $8000 / \mu 1$ [26]. A negative slide was one on which no parasites were seen after examination of at least 200 fields.

\section{Extraction of parasite DNA}

Parasite DNA was extracted from the punched DBS using Chelex ${ }^{\circledR}$-saponin protocol as described elsewhere [27-29] with little modifications. In summary, $50 \mu \mathrm{l}$ of 10\% Saponin and $1 \mathrm{ml}$ Phosphate Buffered Saline (PBS at $\mathrm{pH}$ 7.2) were added to each punched DBS in an Eppendorf tube and left overnight at $4{ }^{\circ} \mathrm{C}$. The filter paper was washed twice in $1 \mathrm{~mL}$ PBS and then heated up to $100 \mathrm{oC}$ in $150 \mu \mathrm{l}$ of sterile distilled water and $50 \mu \mathrm{l}$ of $20 \%$ Chelex $^{\circledR}-100$ (Sigma-Aldrich, USA) for $10 \mathrm{~min}$, with intermittent vortexing. After the final centrifugation step (13,000 rpm for $10 \mathrm{~min})$, the extracted DNA was transferred into a 96-well PCR plate, covered with a plate sealer and stored at $-20^{\circ} \mathrm{C}$ for PCR analysis. 
Molecular detection of Plasmodium falciparum parasites Plasmodium falciparum was detected by a nested PCR amplification, as described previously [30] with minimal modification. The primary reaction mixture was $15 \mu \mathrm{L}$ and contained $2 \mu \mathrm{L}$ of DNA, $0.20 \mu \mathrm{M}$ of each rPLU5 and rPLU6 primers (Eurofins Genomics, Germany), $200 \mu \mathrm{M}$ of each of the four deoxyribonucleotide triphosphates (dNTPs) (Promega Corporation, USA), $3 \mathrm{mM} \mathrm{MgCl}_{2}$ (Sigma-Aldrich, USA) and 0.05 units $/ \mu \mathrm{L}$ of Thermus aquaticus (Taq) DNA polymerase (Sigma-Aldrich, USA). The reaction cycling parameters comprised of an initial denaturation at $94{ }^{\circ} \mathrm{C}$ for $2 \mathrm{~min}$, denaturation at $94{ }^{\circ} \mathrm{C}$ for $1 \mathrm{~min}$, annealing at $55^{\circ} \mathrm{C}$ for $1 \mathrm{~min} 30 \mathrm{~s}$ (all for 30 cycles). Extension was at $72{ }^{\circ} \mathrm{C}$ for $3 \mathrm{~min}$, and a final extension at $72{ }^{\circ} \mathrm{C}$ for $5 \mathrm{~min}$. The secondary reaction mixture was similar to the primary. However, $1 \mu \mathrm{L}$ of the primary PCR product was used as DNA template and with rFal1 and $\mathrm{rFal} 2$ primer set used in the amplification. For nest 2 reaction, the cycling conditions used were as follows, initial denaturation at $95{ }^{\circ} \mathrm{C}$ for $1 \mathrm{~min}$, was followed by denaturation at $94{ }^{\circ} \mathrm{C}$ for $1 \mathrm{~min}$, annealing at $55{ }^{\circ} \mathrm{C}$ for $1 \mathrm{~min} 30 \mathrm{~s}$ (all for 30 cycles). Extension was at $72{ }^{\circ} \mathrm{C}$ for $2 \mathrm{~min}$, and a final extension at $72{ }^{\circ} \mathrm{C}$ for $5 \mathrm{~min}$. The PCR products were stored at $4{ }^{\circ} \mathrm{C}$ until analysis. Positive controls and no DNA template negative control were part of each set of reaction.

\section{Molecular detection of Plasmodium malariae parasites}

Detection of Plasmodium malariae was done according to protocol by Padley and colleagues [31] with some slight modifications. A single reverse primer (Prv) with conserved regions for all four Plasmodium species was used with the species-specific forward primer for $P$. malariae (Pm-F). The reaction mixture contained $0.20 \mu \mathrm{M}$ of each oligonucleotide primers, $200 \mu \mathrm{M}$ of each dNTPs, $3 \mathrm{mM} \mathrm{MgCl}_{2}$ and 0.05 units $/ \mu \mathrm{L}$ of Taq DNA polymerase. Two microlites of DNA was used as the template in a total reaction volume of $15 \mu \mathrm{L}$. Cycling conditions were carried out as follows, initial denaturation at $95{ }^{\circ} \mathrm{C}$ for $5 \mathrm{~min}$, denaturation at $95^{\circ} \mathrm{C}$ for $30 \mathrm{~s}$, annealing at $56.2{ }^{\circ} \mathrm{C}$ for $30 \mathrm{~s}$ (35 cycles). Extension was at $72{ }^{\circ} \mathrm{C}$ for $1 \mathrm{~min}$, and a final extension at $72^{\circ} \mathrm{C}$ for $5 \mathrm{~min}$. The PCR products were stored at $4{ }^{\circ} \mathrm{C}$ until analysis. Positive controls and no DNA template negative control were part of each set of reaction.

\section{PCR product analysis}

PCR products were resolved using a $2 \%$ agarose gel stained with $0.5 \mu \mathrm{g} / \mathrm{mL}$ ethidium bromide electrophoresis. The digital images were then analysed with a Gel Dock (VILBER, France). Gel photographs were scored by visual comparison of DNA fragments for individual samples and estimated using 100 base pair (bp) DNA ladder marker (Promega Corporation, USA). A sample was considered positive if a 205 bp product was detected for $P$. falciparum and 412 bp detected for P. malariae.

\section{Statistical analysis}

Data collected was double-checked before entering onto Epi Data version 3.1 (Odense, Denmark). They were then exported to Stata version 15.0 (StataCorp LLC, Texas, USA) for analysis. Frequency of various findings were expressed as percentages. Descriptive data were summarized as means or proportions. Demographic characteristics (age group, gender, ethnicity, and district), malariometric and anthropometric parameters as well as anaemia were compared among the $\mathrm{Hb}$ classifications using Chi-square or Fischer's exact tests (when the frequencies were less than 5). Binary as well as multi-variate logistic regressions were performed to test for the strength of association observed. Statistical significance was defined as $\mathrm{p}<0.05$.

\section{Results}

\section{Demographic and clinical characteristics of children}

A total of 938 samples from the three districts were analysed. Hohoe Municipality had the highest number of participants 337 (35.9\%), 289 (30.8\%) were from Keta, and 312 (33.3\%) from Krachi West. The mean age of the children was $6.4 \pm 3.4$ years, with $52.6 \%$ being females. Majority of the Children 579 (61.7\%) were aged 5 to11years as compared to the other age groups. Among the ethnic groups, the Ewes constituted 46.8\% (439). Majority of the children 850 (90.6\%) slept inside LLINs the night before the survey as compared to less than $10 \%$ who did not use bed nets the night before the survey $(\mathrm{p}<0.001)$ (Table 1$)$.

\section{Phenotypic and genotypic prevalence of sickle cell disorders \\ Sickling status by Sodium Metabisulfite screening test}

Out of the participants screened, 16.0\% (150/938) were positive by sodium metabisulfite sickling screening test. Among the female participants, $15.4 \%$ (76/493) of them were sickling positive with $16.2 \%$ (49/302) of the children under 5 years also being sickling positive phenotypically. There was no significant difference in the number of sickling positives by metabisulfite screening test from the three districts $(p=0.2406)$. There was no significant difference between the districts, as well as age groups, gender and bed net usage when stratified by sodium metabisulfite test (Table 2).

\section{Sickling status by genotypic analysis}

Using electrophoresis, all the samples were successfully genotyped and the $\mathrm{Hb}$ genotypes detected in 
Table 1 Socio-demographic characteristics of study participants stratified by district

\begin{tabular}{|c|c|c|c|c|c|}
\hline Variable & Hohoe $(n=337)$ & Keta $(n=289)$ & Krachi $(n=312)$ & Total $(n=938)$ & $p$-value \\
\hline \multicolumn{6}{|l|}{ Gender (\%) } \\
\hline Female & $183(54.3)$ & $147(50.9)$ & $163(52.2)$ & $493(52.6)$ & \\
\hline Male & $154(45.7)$ & $142(49.1)$ & $149(47.8)$ & $445(47.4)$ & 0.6855 \\
\hline Mean age $(s d)$ & $5.6(3.3)$ & $7.0(3.0)$ & $6.7(3.6)$ & & $<0.0004$ \\
\hline \multicolumn{6}{|l|}{ Age categories (\%) } \\
\hline $1-4 y r s$ & $136(40.3)$ & $66(22.8)$ & $100(32.1)$ & $302(32.2)$ & \\
\hline $5-11 y r s$ & $185(54.9)$ & $203(70.2)$ & $191(61.2)$ & $579(61.7)$ & \\
\hline Above 12 years & $16((4.7)$ & $20(7.0)$ & $21(6.7)$ & $57(6.1)$ & 0.0002 \\
\hline \multicolumn{6}{|l|}{ Ethnicity (\%) } \\
\hline Akan & $8(2.4)$ & $7(2.4)$ & $10(3.2)$ & $25(2.7)$ & \\
\hline Ewe & $133(39.5)$ & $281(97.2)$ & $25(8.0)$ & $439(46.8)$ & \\
\hline Guan & $33(9.8)$ & $0(0.0)$ & $148(47.4)$ & $181(19.3)$ & \\
\hline Others & $163(48.3)$ & $1(0.4)$ & $129(41.4)$ & $293(31.2)$ & $<0.0004$ \\
\hline \multicolumn{6}{|l|}{ Bed net use (\%) } \\
\hline No & $48(14.2)$ & $15(5.2)$ & $25(8.0)$ & $88(9.4)$ & \\
\hline Yes & $289(85.8)$ & $274(94.8)$ & $287(92.0)$ & 850 (90.6) & 0.0003 \\
\hline Mean Parasite Density/ $\mu \mathrm{L}(\mathrm{sd})$ & $20,983.5(64,810.2)$ & $7255.7(12,667.2)$ & $100,808.6(191,698.9)$ & & 0.0406 \\
\hline Mean Hb g/dL(sd) & $11.2(1.7)$ & $10.5(1.3)$ & $11.6(1.6)$ & $11.1(1.6)$ & $<0.0004$ \\
\hline \multicolumn{6}{|l|}{ HAZ } \\
\hline Normal & $254(75.4)$ & $234(81.0)$ & $259(83.0)$ & $747(79.6)$ & \\
\hline Stunted & $83(24.6)$ & $55(19.0)$ & $53(17.0)$ & 191 (20.4) & 0.0430 \\
\hline
\end{tabular}

Table 2 Demographic characteristics of the study participants stratified by metabisulfite screening test

\begin{tabular}{|c|c|c|c|c|}
\hline Variable & Negative $(n=788)$ & Positive $(n=150)$ & Total $(n=938)$ & $p$-value \\
\hline \multicolumn{5}{|l|}{ District (\%) } \\
\hline Hohoe & $279(35.4)$ & $58(38.7)$ & $337(35.9)$ & \\
\hline Keta & $238(30.2)$ & $51(34.0)$ & $289(30.8)$ & \\
\hline Krachi & $271(34.4)$ & $41(27.3)$ & $312(33.3)$ & 0.2406 \\
\hline \multicolumn{5}{|l|}{ Gender (\%) } \\
\hline Female & $417(52.9)$ & $76(50.7)$ & $493(52.6)$ & \\
\hline Male & $371(47.1)$ & $74(49.3)$ & $445(47.4)$ & 0.6766 \\
\hline \multicolumn{5}{|l|}{ Age (\%) } \\
\hline $1-4 y r s$ & $253(32.1)$ & $49(32.7)$ & $302(32.2)$ & \\
\hline $5-11 y r s$ & $486(61.7)$ & $93(62.0)$ & $579(61.7)$ & \\
\hline Above $12 \mathrm{yrs}$ & $49(6.2)$ & $8(5.3)$ & $57(6.1)$ & 0.9154 \\
\hline \multicolumn{5}{|l|}{ Bed net use (\%) } \\
\hline No & $77(9.8)$ & $11(7.3)$ & $88(9.4)$ & \\
\hline Yes & $711(90.2)$ & $139(92.7)$ & $850(90.6)$ & 0.4319 \\
\hline
\end{tabular}

this study were predominantly the HbAA type $(70.8 \%$; 664/938), followed by the heterozygous HbAS (14.0\%; $131 / 938)$ and $\operatorname{HbAC}(10.8 \% ; 101 / 938)$. The minor genotypes detected were $\operatorname{HbAF}(1.9 \% ; 18 / 938), \mathrm{HbCC}(0.4 \%$; $4 / 938), \operatorname{HbSC}(0.6 \% ; 6 / 938), \operatorname{HbSF}(0.9 \% ; 8 / 938)$ and HbSS $(0.2 \% ; 2 / 938)$. In addition to these genotypes, HbACF $(0.1 \% ; 1 / 938)$ and $\operatorname{HbSCF}(0.3 \% ; 3 / 938)$ genotypes that had three separate bands were detected. The overall prevalence of sickle cell disorders ( $\mathrm{HbSS}, \mathrm{HbSC}$, $\mathrm{HbSF}$ and $\mathrm{HbSCF}$ ) in this study was $2.0 \%$. The difference in the distribution of normal genotype, sickle cell disorders, sickle cell trait and "other $\mathrm{Hb}$ disorders" among the 3 districts was statistically significant $(p<0.001)$ (Fig. 2). Sodium Metabisulphite test is used to differentiate cells which have sickle haemoglobin from those that do not have. However, the IEF is used 


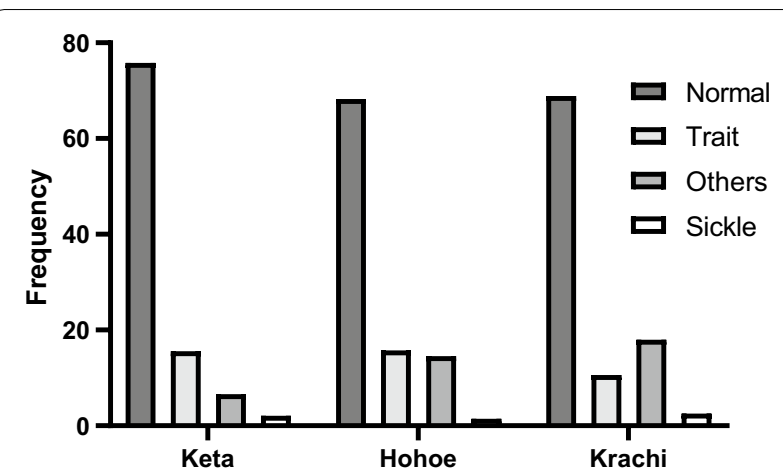

Fig. 2 Prevalence of haemoglobin classifications within the study population. Normal $=\mathrm{Hb}$ AA, Trait $=\mathrm{HbAS}$, Sickle Cell Disorders $=\mathrm{HbSS}, \mathrm{HbSC}, \mathrm{HbSF}$ and $\mathrm{HbSCF}$ and Other $\mathrm{Hb}$ Disorders $=(\mathrm{HbAC}, \mathrm{HbCC}, \mathrm{HbAF}$ and $\mathrm{HbACF})$. The error bars represent 95\% Cl for prevalence of $\mathrm{Hb}$ classification $(p<0.001)$

to determine the exact genotypes of these cells, hence the difference in the numbers.

\section{Malariometric indices}

The overall prevalence of $P$. falciparum infection by microscopy in the study population was 5.5\% (52/938), whereas sub-microscopic P. falciparum infection by PCR was $14.2 \%$ (133/938). Fever was present in 10.1\% (95/938) of the participants. Children with sickle cell disorders had a higher proportion of sub-microscopic parasitaemia compared to those with other conditions $(p=0.0004)$ (Table 3). Factors predicting sub-microscopic carriage in the three districts were analysed using multiple logistic regression with sub-microscopic parasitaemia as a binary outcome. It was observed that children with sickle cell disorders were 5.51 times more likely to have sub-microscopic parasitaemia, compared to those with normal genotype $(\mathrm{AOR}=5.51$ : $95 \% \mathrm{CI}(2.15,14.10), p<0.001)$.
Also, children in the 5-11 year group are more likely to have sub-microscopic parasitaemia compared to children under five (5) years $(\mathrm{AOR}=1.87: 95 \% \mathrm{CI}(1.20,2.90)$, $p=0.006)$. The geographical location (district), and gender did not influence carriage of sub-microscopic parasitaemia (Table 4).

\section{The association of anaemia and sickle cell disorders among children}

The overall mean $\mathrm{Hb}$ measured was $11.1 \pm 1.4 \mathrm{~g} / \mathrm{dL}$. Children from Keta District had significantly lower $\mathrm{Hb}$ $(10.5 \pm 1.3)$ compared to Hohoe Municipality (11.2 \pm 1.7$)$, and Krachi West District $(11.6 \pm 1.6) \quad(p<0.0004)$ (Table 1). The mean $\mathrm{Hb}$ for those with sickle cell disorders $9.1 \pm 2.4 \mathrm{~g} / \mathrm{dL}$, was significantly lower than normal $(\mathrm{Hb}: 11.2 \pm 1.6 \mathrm{~g} / \mathrm{dL}$, sickle cell trait:10.9 $\pm 1.5 \mathrm{~g} / \mathrm{dL}$ and other $\mathrm{Hb}$ disorders: $11.4 \pm 1.7 \mathrm{~g} / \mathrm{dL}$ ). The prevalence of anaemia among children with sickle cell disorders was $73.7 \%$ (14/19) (Fig. 3). Sickle cell disorders influenced the anaemia status of the study participants (Table 5).

\section{Influence of sickle cell disorders on growth and development of children}

From the study, although about 19\% of the participants were underweight, and $20 \%$ were stunted, no association was observed between the various haemoglobin disorders and the anthropometric indices of the children in this study (Additional file 1: Table S2).

\section{Discussion}

This cross-sectional study sought to determine the prevalence of sickle cell disorders and malaria infection among children aged 1-12 years in the Volta region of Ghana. The ethnical background of the participants showed the Ewes dominating, but that was not surprising because

Table 3 Haemoglobin classification and malaria indices

\begin{tabular}{|c|c|c|c|c|c|c|}
\hline Variables & Normal $(n=664)$ & $\begin{array}{l}\text { Other } \mathrm{Hb} \text { disorders } \\
(\mathrm{n}=124)\end{array}$ & $\begin{array}{l}\text { Sickle cell } \\
\text { disorders } \\
(n=19)\end{array}$ & $\begin{array}{l}\text { Sickle cell trait } \\
(n=131)\end{array}$ & Total $(n=938)$ & $p$-value \\
\hline \multicolumn{7}{|c|}{ Sub-microscopic parasitaemia (\%) } \\
\hline Negative & $573(86.3)$ & $110(88.7)$ & $10(52.6)$ & $112(85.4)$ & $805(85.8)$ & \\
\hline Positive & $91(13.7)$ & $14(11.3)$ & $9(47.4)$ & $19(14.5)$ & $133(14.2)$ & 0.0004 \\
\hline \multicolumn{7}{|c|}{ Parasite by microscopy (\%) } \\
\hline Negative & $626(94.3)$ & $121(97.6)$ & $17(89.5)$ & $122(93.1)$ & $886(94.5)$ & \\
\hline Positive & $38(5.7)$ & $3(2.4)$ & $2(10.5)$ & $9(6.9)$ & $52(5.5)$ & 0.2965 \\
\hline \multicolumn{7}{|l|}{ Fever $(\%)$} \\
\hline Fever & $76(11.4)$ & $10(8.1)$ & $3(15.8)$ & $6(4.6)$ & $95(10.1)$ & \\
\hline No fever & $588(88.6)$ & $114(91.9)$ & $16(84.2)$ & $125(95.4)$ & $843(89.9)$ & 0.0736 \\
\hline $\begin{array}{l}\text { Mean haemoglobin } \\
\quad(\mathrm{SD})(\mathrm{g} / \mathrm{dL})\end{array}$ & $11.2(1.6)$ & $11.4(1.7)$ & $9.1(2.4)$ & $10.9(1.5)$ & $11.1(1.6)$ & $<0.0004$ \\
\hline
\end{tabular}


Table 4 Factors influencing sub-microscopic parasitaemia among study participants

\begin{tabular}{|c|c|c|c|c|c|}
\hline \multirow{2}{*}{$\begin{array}{l}\text { Variables } \\
\text { Sex }\end{array}$} & \multicolumn{2}{|c|}{ Sub-microscopic parasitaemia } & \multirow[t]{2}{*}{$x^{2}$ ( $p$ value) } & \multirow[t]{2}{*}{ COR $(95 \% \mathrm{Cl}), p$ value } & \multirow[t]{2}{*}{ AOR $(95 \% \mathrm{Cl}), p$ value } \\
\hline & Negative & Positive & & & \\
\hline Female & $417(51.8)$ & $76(57.1)$ & & Ref. & \\
\hline Male & $388(48.2)$ & $58(42.9)$ & $1.11(0.291)$ & $0.82(0.57,1.18), 0.292$ & \\
\hline \multicolumn{6}{|l|}{ Age group } \\
\hline $1-4$ & $274(34.0)$ & $28(21.5)$ & & Ref. & Ref. \\
\hline $5-11$ & $481(59.8)$ & $98(73.7)$ & & $1.92(1.24,2.99), 0.004$ & $1.87(1.20,2.90), \mathbf{0 . 0 0 6}$ \\
\hline$\geq 12$ & $50(6.2)$ & $7(5.3)$ & $8.95(0.011)$ & $1.29(0.54,3.11), 0.567$ & $1.14(0.46,2.80), 0.777$ \\
\hline \multicolumn{6}{|l|}{ District } \\
\hline Keta Municipality & $253(31.4)$ & $36(27.1)$ & & Ref. & \\
\hline Hohoe Municipality & $291(36.2)$ & $46(34.6)$ & & $1.11(0.70,1.77), 0.659$ & \\
\hline Krachi West & $261(32.4)$ & $51(38.4)$ & $2.288(0.319)$ & $1.40(0.88,2.21), 0.150$ & \\
\hline \multicolumn{6}{|l|}{ Hb classification } \\
\hline Normal & $573(71.2)$ & $91(68.4)$ & & Ref. & Ref. \\
\hline Trait & $112(13.9)$ & $19(14.3)$ & & $1.06(0.63,1.82), 0.809$ & $1.07(0.63,1.84), 0.793$ \\
\hline Other $\mathrm{Hb}$ disorders & $110(13.7)$ & $14(10.5)$ & & $0.88(0.48,1.82), 0.608$ & $0.86(0.47,1.54), 0.605$ \\
\hline Sickle cell disorders & $10(1.2)$ & $9(6.8)$ & $17.72(0.001)$ & $5.67(2.24,14.32),<0.001$ & $5.51(2.15,14.10),<\mathbf{0 . 0 0 1}$ \\
\hline
\end{tabular}

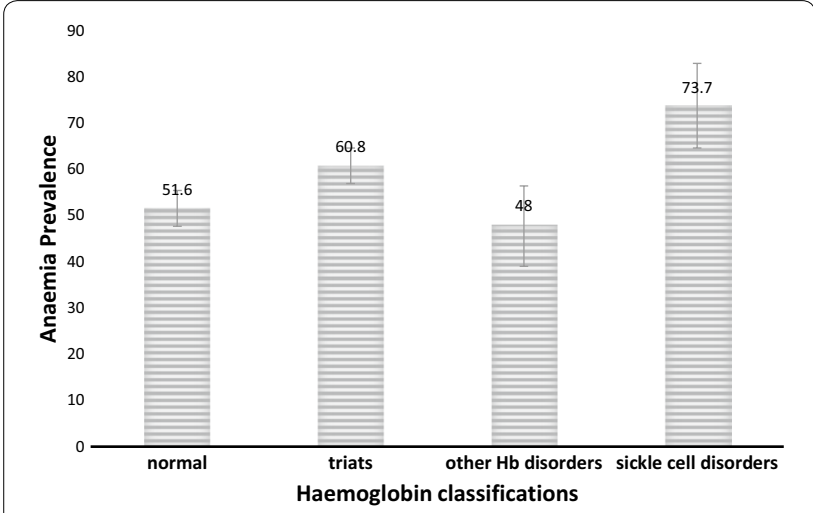

Fig. 3 Prevalence of anaemia among the children with and without sickle cell disorders. The error bars show $95 \% \mathrm{Cl}$ of anaemia prevalence among the $\mathrm{Hb}$ classifications $(p=0.042)$

they are the majority within the region [32]. There was a higher number of LLIN use among participants (90.6\%) compared to $47 \%$ from the Ghana Demographic Health Survey Report from the same community [33], as well as 41.7 and $72.8 \%$ in other parts of the region [33-35]. Also, in Asutsuare in the Greater Accra Region, bed net usage was lower (56\%) as compared to what was observed in this study. This suggests that education on LLIN usage as part of the malaria control efforts is gradually being accepted in the study communities.

The prevalence of sickling positive was $16.0 \%$, which was higher than $6.0 \%$ detected previously among children in Asutsuare, in the Greater Accra Region, the higher prevalence of sickling positive observed in this population, could be due to the higher sickling gene pool found in the Volta Region compared to others [36]. However, among the study population, the number of males found to be sickling positive were higher than females. This was contrary to the findings of Antwi-Baffour and colleagues, that observed a higher prevalence of sickling positives (41.7\%), among females compared to males [37]. These differences in prevalence could be due to variations in sample size and the geographical locations of where these studies were done.

The overall prevalence of sickle cell disorders which consists of HbSS, HbSC, HbSF and HbSCF was $2.0 \%$, this was found to be higher than the $0.3-1.2 \%$ prevalence levels observed in other studies done in the country [38-40]. The high prevalence observed in this study could be due to the high throughput method used to detect the haemoglobin genotypes. It could also probably be that the sickling gene pool in this study site is higher than those from other sites. The prevalence of the individual genotypes that were classified as sickle cell disorders revealed that genotype $\mathrm{HbSC}$ had a higher prevalence than HbSS. This observation is similar to other studies conducted in Ghana [38, 39, 41] and Burkina Faso [42]. It was however contrary to the findings of studies done in Nigeria [43, $44]$ and in Ghana (Accra) [19, 45]. Interestingly, genotype $\mathrm{HbSF}$ was observed in $0.9 \%$ of the participants, this genotype is rarely detected in most studies with children, since it has been shown to wane off in early childhood by 6 months of age [46, 47]. A study that reviewed records of children in a referral hospital in Ghana observed levels $(0.8 \%)$ of HbSF [45] that was very close to what was observed in this study. Though fetal haemoglobin (HbF) 
Table 5 Factors influencing anaemia among study participants

\begin{tabular}{|c|c|c|c|c|c|}
\hline Variables & Anaemia & & $x^{2}$ ( $p$ value $)$ & COR $(95 \% \mathrm{Cl}), \mathrm{p}$ value & AOR $(95 \% \mathrm{Cl}), p$ value \\
\hline Sex & No anaemia & Anaemia & & & \\
\hline Female & $250(56.3)$ & $243(49.2)$ & & Ref. & Ref. \\
\hline Male & $194(43.7)$ & $251(50.8)$ & $4.64(0.031)$ & $1.32(1.03,1.72), 0.031$ & $1.30(0.96,1.67), 0.091$ \\
\hline \multicolumn{6}{|l|}{ Age group } \\
\hline $1-4$ & $121(27.2)$ & $181(36.6)$ & & Ref. & Ref. \\
\hline $5-11$ & $296(66.7)$ & $283(57.3)$ & & $0.63(0.48,0.84), 0.002$ & $0.53(0.39,0.72),<\mathbf{0 . 0 0 1}$ \\
\hline$\geq 12$ & $27(6.1)$ & $30(6.1)$ & $10.12(0.006)$ & $0.70(0.40,1.23), 0.224$ & $0.59(0.32,1.08), 0.086$ \\
\hline \multicolumn{6}{|l|}{ District } \\
\hline Keta Municipality & $79(17.8)$ & $210(42.5)$ & & Ref. & Ref. \\
\hline Hohoe municipality & $176(39.6)$ & $161(32.6)$ & & $0.34(0.24,0.48),<0.001$ & $0.30(0.21,0.42),<\mathbf{0 . 0 0 1}$ \\
\hline Krachi West & $189(42.6)$ & $123(24.9)$ & $71.90(<0.001)$ & $0.24(0.17,0.34),<0.001$ & $0.23(0.16,0.33),<\mathbf{0 . 0 0 1}$ \\
\hline \multicolumn{6}{|l|}{ Malaria microscopy } \\
\hline Negative & $424(95.5)$ & $462(93.5)$ & & Ref. & \\
\hline Positive & $20(4.5)$ & $32(6.5)$ & $1.67(0.196)$ & $1.46(0.82,2.59), 0.198$ & \\
\hline \multicolumn{6}{|l|}{ Sub-microscopic malaria } \\
\hline Negative & $389(87.6)$ & $416(84.2)$ & & Ref. & \\
\hline Positive & $55(12.4)$ & $78(15.8)$ & $1.81(0.178)$ & $1.29(0.89,1.87), 0.179$ & \\
\hline \multicolumn{6}{|l|}{ HAZ } \\
\hline Normal & $373(83.8)$ & $375(75.9)$ & & Ref. & Ref. \\
\hline Stunting & $72(16.2)$ & $119(24.1)$ & $7.15(0.008)$ & $1.56(1.12,2.16), 0.008$ & $1.44(1.02,2.05), \mathbf{0 . 0 3 7}$ \\
\hline \multicolumn{6}{|l|}{ Hb classification } \\
\hline Normal & $322(72.5)$ & $342(69.2)$ & & Ref. & \\
\hline Trait & $52(11.7)$ & $79(16.0)$ & & $1.45(1.00,2.13), 0.056$ & $1.03(0.68,1.56), 0.898$ \\
\hline Other $\mathrm{Hb}$ disorders & $65(14.6)$ & $59(11.9)$ & & $0.86(0.59,1.27), 0.461$ & $1.37(0.91,2.06), 0.136$ \\
\hline Sickle cell disorders & $5(1.1)$ & $14(2.8)$ & $8.18(0.042)$ & $2.62(0.94,7.38), 0.067$ & $3.03(1.04,8.82), \mathbf{0 . 0 4 2}$ \\
\hline
\end{tabular}

levels have been associated with protection of children from severe sickle cell crisis [47, 48], disease severity may increase when it persists into adulthood, thus have implications for sickle cell management.

The prevalence of malaria infection using PCR was higher than that of microscopy (14.0\% versus $5.5 \%)$. The molecular detection of parasites by PCR has been shown to be more sensitive than microscopy in several studies $[36,38,49,50]$. Children with sickle cell disorders (HbSS) had a significantly higher proportion of sub-microscopic parasitaemia than those with sickle cell trait (HbAS) and other $\mathrm{Hb}$ disorders $(p=0.001)$. This is probably due to immune regulation, that results in the suppression of parasites below microscopic detection limit in sickle cell individuals [38], hence their low parasitaemia. Thus it buttresses the established fact that sickle cell trait confers protection against clinical malaria [1, 12-14]. Also, children with sickle cell disorders were found to be 5.5 times more likely to have sub-microscopic parasitaemia than those with normal genotype $(\mathrm{AOR}=5.5195 \% \mathrm{CI}$ $(2.15,14.10), p<0.001)$. A similar observation was made in a study conducted in Ghana, which found HbSC (a sickle cell disorder) to have a higher proportion of sub-microscopic $P$. falciparum infection than those with HbAA $(\mathrm{AOR}=4.34$ 95\% CI (1.36-13.9)) [38].

The mean $\mathrm{Hb}$ levels recorded was lower in children with sickle cell disorders compared to those with normal genotype $(9.1 \pm 2.4$ against $11.4 \pm 1.6 \mathrm{~g} / \mathrm{dL})$. In addition, children with sickle cell disorders were 3 times more likely to be anaemic compared to those with normal genotype $(\mathrm{AOR}=3.0395 \% \mathrm{CI}(1.04,8.82), p=0.042)$. This is not surprising, because there is evidence that the halflife of haemoglobin in sickle cell individuals is shorter than normal haemoglobin and are rapidly destroyed by the spleen because of their abnormal shape, thus such patients tend to have chronic anaemia [12, 15]. This observation was similar to findings from a study from parts of Ghana [38] but different from what was observed in Burkina Faso, where children with normal genotype had a lower mean $\mathrm{Hb}$ than those with $\mathrm{HbSS}$ or $\mathrm{HbSC}$ [42]. This could be as a result of other infections such as clinical malaria or severe malaria anaemia and malnutrition in these children.

The majority of children screened in this study were stunted. This finding could be an indication of the low socio-economic conditions in the communities 
surveyed. This observation was similar to what was found in a study conducted in Northern Ghana [51]. In this study, there was no significant association between sickle cell disorders and the growth and development of the children. However, a study conducted in the Ashanti region of Ghana, observed a significantly lower risk of stunting in children with sickle cell trait than among those with HbAA $(p=0.035)$ [39]. Another study conducted in Kinshasa observed a significantly higher proportion of subjects with stunting and underweight among SCA under 12 years $(p<0.001)$ compared to those with HbAA [52].

The limitations of this study were that information on bed net usage was obtained from parents/guardians of the children without direct observation to confirm the availability and use. Also, the study was conducted at one time in the year, the study was not conducted at different malaria transmission seasons in these communities, therefore, the impact of seasonality on malaria and anaemia could not be determined.

\section{Conclusions}

Sickle cell disorders were significantly associated with sub-microscopic parasitaemia infection as well as anaemia. Association between sickle cell disorders and growth and development of study participants could not be ascertained. More sensitive molecular techniques must be used when conducting research on haemoglobin disorders, so as to detect silent genotypes that may be prevalent. Establishment of sickle cell clinics in the district and regional hospitals will help in the management of children with sickle cell disorders as well as to help in generating national data on sickle cell disorders. Also, neonatal screening in all regions of the country will be an effective way for early detection to inform efficient management of these disorders.

\section{Supplementary information}

Supplementary information accompanies this paper at https://doi. org/10.1186/s12936-020-03500-5.

Additional file 1: Table S1. Haemoglobin classification from isoelectric focussing analysis. Table S2. Distribution of anthropometric indices among the haemoglobin classifications.

\section{Abbreviations}

AA: Normal Haemoglobin; AC: Heterozygous for haemoglobin C; AS: Sickle trait; BAZ: Body mass index-for-age; CC: Homozygote for haemoglobin C; DBS: Dried blood spots; DNA: Deoxyribonucleic Acid; Hb: Haemoglobin; HAZ: Height-for-age; IEF: Isoelectric focusing; SC: Haemoglobins S and C; SS: Sickle cell; Sickle cell disorders: Haemoglobin HbSF, HbSCF, HbACF sickle $\beta$-thalassemia disease (S/ $\beta$ thal); HbS/HPFH: HbS/Hereditary persistence of fetal haemoglobin; HbSF: Fetal haemoglobin; LLIN: Long-Lasting Insecticide Net; MUAC: Mid Upper Arm Circumference; PCR: Polymerase Chain Reaction; REC: Research Ethics Committee; WAZ: Weight-for-age.

\section{Acknowledgements}

Our gratitude goes to the staff of the Department of Epidemiology and Biostatistics, School of Public Health, University of Health and Allied Sciences, Hohoe, and the Immunology Department, Noguchi Memorial Institute for Medical Research, University of Ghana for technical, field and laboratory support. We also thank all the Field Support staff, especially the supervisors for their enormous support during the sample collection. Again, we do express our appreciation to the management and staff of the three health facilities in facilitating the work. We are also grateful to all the study participants, especially the parents/Guardians of the children.

\section{Author contributions}

$\mathrm{MO}, \mathrm{MFO}$ and MK conceived and designed the study, MO, EKB, EAO, BT, BA assisted in the sampling, laboratory experiments and data analysis; MO, EKB, MFO, MK and HL assisted in data analysis and manuscript writing; All authors reviewed the manuscript.

\section{Funding}

The study was jointly supported by the Danish Research Council for Development Research (FFU) led by Professor Lars Hviid and MFO (Grant No. 17-02$\mathrm{KU}$ ) and the School of Public Health, University of Health and Allied Sciences, Ghana.

\section{Availability of Data and Material}

The datasets analysed for this study are included in the article, additional data required are available from the corresponding author on reasonable request.

\section{Ethics approval and consent to participate}

The study was approved by the Research Ethics Committee (REC) of the University of Health and Allied Sciences (UHAS-REC A.1 (5) 18 -19). Permission was sought from the Regional Health Director as well as Health and Education Directorates of each of the districts. Permission was also sought from the chiefs and elders in the selected communities. A written informed consent was obtained from the parents/guardians of the participants.

\section{Consent for publication}

Not applicable.

\section{Competing interests}

The authors declare that they have no competing interests.

\section{Author details}

${ }^{1}$ Department of Epidemiology and Biostatistics, School of Public Health, University of Health and Allied Sciences, Hohoe, Ghana. ${ }^{2}$ Department of Immunology, Noguchi Memorial Institute for Medical Research, College of Health Sciences, University of Ghana, Accra, Ghana.

Received: 21 May 2020 Accepted: 15 November 2020

Published online: 23 November 2020

References

1. Forget BG, Bunn HF. Classification of the disorders of hemoglobin. Cold Spring Harb Perspect Med. 2013;3:a011684.

2. Tsaras G, Owusu-Ansah A, Boateng FO, Amoateng-Adjepong Y. Complications associated with sickle cell trait: a brief narrative review. Am J Med. 2009;122:507-12

3. Modell B, Darlison M. Global epidemiology of haemoglobin disorders and derived service indicators. Bull World Health Organ. 2008;86:480-7.

4. Lewis SM, Bain BJ, Bates I, Dacie JV. Dacie and Lewis practical haematology. 10th ed. London: Churchill Livingstone Publishers; 2006.

5. Bunn HF. Pathogenesis and treatment of sickle cell disease. N Engl J Med. 1997;337:762-9.

6. Meier ER, Miller JL. Sickle cell disease in children. Drugs. 2012;72:895-906.

7. Soale A. Dealing with sickle cell disease in Ghana: modern Ghana; 2015. Available from: https://www.modernghana.com/news/635897/

8. Rees DC, Williams TN, Gladwin MT. Sickle-cell disease. Lancet. 2010;376:2018-31.

9. Aygun B, Odame I. A global perspective on sickle cell disease. Pediatr Blood Cancer. 2012;59:386-90. 
10. Piel FB, Hay SI, Gupta S, Weatherall DJ, Williams TN. Global burden of sickle cell anaemia in children under five, 2010-2050: modelling based on demographics, excess mortality, and interventions. PLoS Med. 2013;10:e1001484.

11. Weatherall DJ. Hemoglobinopathies worldwide: present and future. Curr Mol Med. 2008:8:592-9.

12. Taylor SM, Parobek CM, Fairhurst RM. Haemoglobinopathies and the clinical epidemiology of malaria: a systematic review and meta-analysis. Lancet Infect Dis. 2012;12:457-68.

13. Aidoo M, Terlouw DJ, Kolczak MS, McElroy PD, ter Kuile FO, Kariuki S, et al. Protective effects of the sickle cell gene against malaria morbidity and mortality. Lancet. 2002;359:1311-2.

14. Allison AC. The distribution of the sickle-cell trait in East Africa and elsewhere, and its apparent relationship to the incidence of subtertian malaria. Trans R Soc Trop Med Hyg. 1954;48:312-8.

15. Williams TN. Balancing act: haemoglobinopathies and malaria. Lancet Infect Dis. 2012;12:427-8.

16. Williams TN, Mwangi TW, Roberts DJ, Alexander ND, Weatherall DJ, Wambua $\mathrm{S}$, et al. An immune basis for malaria protection by the sickle cell trait. PLoS Med. 2005;2:e128.

17. Pecker LH, Schaefer BA, Luchtman-Jones L. Knowledge insufficient: the management of haemoglobin SC disease. Br J Haematol. 2017;176:515-26.

18. Edwin AK, Edwin F, Etwire V. Controlling sickle cell disease in Ghana ethics and options. Pan Afr Med J. 2011;10:14.

19. Asare EV, Wilson I, Kuma B-A, Amma A, Dei-Adomakoh Y, Sey F, et al. Burden of sickle cell disease in Ghana: the Korle-Bu Experience. Adv Hematol. 2018;2018:6161270.

20. Ohene-Frempong K, Oduro J, Tetteh H, Nkrumah FJP. Screening newborns for sickle cell disease in Ghana. Pediatrics. 2008;121:S120-1.

21. Ndeezi G, Kiyaga C, Hernandez AG, Munube D, Howard TA, Ssewanyana I, et al. Burden of sickle cell trait and disease in the Uganda Sickle Surveillance Study (US3): a cross-sectional study. Lancet Glob Health. 2016;4:e195-200.

22. Kweku M, Liu D, Adjuik M, Binka F, Seidu M, Greenwood B, et al. Seasonal intermittent preventive treatment for the prevention of anaemia and malaria in Ghanaian children: a randomized, placebo controlled trial. PLoS ONE. 2008;3:e4000.

23. Afari EA, Akanmori BD, Nakano T, Ofori-Adjei D. Plasmodium falciparum: sensitivity to chloroquine in vivo in three ecological zones in Ghana. Trans $R$ Soc Trop Med Hyg. 1992;86:231-2.

24. Van den Broeck J, Willie D, Younger N. The World Health Organization child growth standards: expected implications for clinical and epidemiological research. Eur J Pediatr. 2009;168:247-51.

25. WHO. Haemoglobin concentrations for the diagnosis of anaemia and assessment of severity. Vitamin and mineral nutrition information system. Geneva, World Health Organization, 2011.

26. WHO and Center for Disease Control. Basic malaria microscopy: tutor's guide. Geneva: World Health Organization; 2010.

27. Wangai LN, Karau MG, Njiruh PN, Sabah O, Kimani FT, Magoma G, et al. Sensitivity of microscopy compared to molecular diagnosis of P. falciparum: implications on malaria treatment in epidemic areas in Kenya. Afr J Infect Dis. 2011;5:1-6.

28. Miguel RB, Coura JR, Samudio F, Suárez-Mutis MC. Evaluation of three different DNA extraction methods from blood samples collected in dried filter paper in Plasmodium subpatent infections from the Amazon region in Brazil. Rev Inst Med Trop S Paulo. 2013;55:205-8.

29. Moll K, Kaneko A, Scherf A, Wahlgren M. Methods in malaria research. Sixth ed: MR4. ATCC; 2013

30. Snounou G, Viriyakosol S, Jarra W, Thaithong S, Brown KN. Identification of the four human malaria parasite species in field samples by the polymerase chain reaction and detection of a high prevalence of mixed infections. Mol Biochem Parasitol. 1993;58:283-92.

31. Padley D, Moody A, Chiodini P, Saldanha J. Use of a rapid, single-round, multiplex PCR to detect malarial parasites and identify the species present. Ann Trop Med Parasitol. 2003;97:131-7.

32. Asante R, Gyimah-Boadi E. Ethnic structure, inequality and governance of the public sector in Ghana. Geneva: UNRISD; 2004.

33. Ghana Statistical Service (GSS), Ghana Health Service (GHS), ICF International. Ghana demographic and health survey 2014. 2015, Rockville, Maryland
34. Diema Konlan K, Japiong M, Dodam Konlan K, Afaya A, Salia SM, Kombat JM. Utilization of insecticide treated bed nets (ITNs) among caregivers of children under five years in the Ho municipality. Interdiscip Perspect Infect Dis. 2019;2019:3693450.

35. Kweku M, Takramah W, Takase M, Tarkang E, Adjuik M. Factors associated with malaria prevalence among children under five years in the hohoe municipality of Ghana. JTransm Dis Immun. 2017;1:2.

36. Lamptey H, Ofori MF, Kusi KA, Adu B, Owusu-Yeboa E, Kyei-Baafour E, et al. The prevalence of submicroscopic Plasmodium falciparum gametocyte carriage and multiplicity of infection in children, pregnant women and adults in a low malaria transmission area in Southern Ghana. Malar J. 2018;17:331.

37. Antwi-Baffour S, Asare RO, Adjei JK, Kyeremeh R, Adjei DN. Prevalence of hemoglobin $S$ trait among blood donors: a cross-sectional study. BMC Res Notes. 2015;8:583.

38. Danquah I, Ziniel P, Eggelte TA, Ehrhardt S, Mockenhaupt FP. Influence of haemoglobins $\mathrm{S}$ and $\mathrm{C}$ on predominantly asymptomatic Plasmodium infections in northern Ghana. Trans R Soc Trop Med Hyg. 2010;104:713-9.

39. Kreuels B, Kreuzberg C, Kobbe R, Ayim-Akonor M, Apiah-Thompson P, Thompson $\mathrm{B}$, et al. Differing effects of $\mathrm{HbS}$ and $\mathrm{HbC}$ traits on uncomplicated falciparum malaria, anemia, and child growth. Blood. 2010;115:4551-8.

40. Amoako N, Asante KP, Adjei G, Awandare GA, Bimi L, Owusu-Agyei S. Associations between red cell polymorphisms and Plasmodium falciparum infection in the middle belt of Ghana. PLOS ONE. 2014;9:e112868.

41. Baah AT, Azumah DE, Ampiah C, Boampong J, Nuvor SV. Incidence of human immunodeficiency virus in sickle cell patients in the Cape Coast Metropolis. Ghana World J AIDS. 2014;4:338-45.

42. Bougouma EC, Tiono AB, Ouédraogo A, Soulama I, Diarra A, Yaro J-B, et al. Haemoglobin variants and Plasmodium falciparum malaria in children under five years of age living in a high and seasonal malaria transmission area of Burkina Faso. Malar J. 2012;11:154.

43. Fleming A, Storey J, Molineaux L, Iroko E, Attai ED. Abnormal haemoglobins in the Sudan savanna of Nigeria: I. Prevalence of haemoglobins and relationships between sickle cell trait, malaria and survival. Ann Trop Med Parasitol. 1979;73:161-72.

44. Uzoegwu PN, Onwurah AJB. Prevalence of haemoglobinopathy and malaria diseases in the population of old Aguata Division, Anambra State. Nigeria Biokemistri. 2003;15:57-66.

45. Boadu I, Ohemeng A, Renner LA. Dietary intakes and nutritional status of children with sickle cell disease at the Princess Marie Louise Hospital. Accra Surv BMC Nutr. 2018;4:33.

46. Platt OS, Thorington BD, Brambilla DJ, Milner PF, Rosse WF, Vichinsky E, et al. Pain in sickle cell disease: rates and risk factors. N Engl J Med. 1991;325:11-6.

47. Edoh D, Antwi-Bosaiko C, Amuzu D. Fetal hemoglobin during infancy and in sickle cell adults. Afr Health Sci. 2006;6:51-4.

48. Powars DR, Weiss JN, Chan LS, Schroeder W. Is there a threshold level of fetal hemoglobin that ameliorates morbidity in sickle cell anemia? Blood. 1984;63:921-6.

49. Dinko B, Ayivor-Djanie R, Abugri J, Agboli E, Kye-Duodu G, Tagboto S, et al. Comparison of malaria diagnostic methods in four hospitals in the Volta region of Ghana. Malaria World J. 2016;7:1-6.

50. Siwal N, Singh US, Dash M, Kar S, Rani S, Rawal C, et al. Malaria diagnosis by PCR revealed differential distribution of mono and mixed species infections by Plasmodium falciparum and P. vivax in India. PLOS ONE. 2018;13:e0193046.

51. Ali Z, Saaka M, Adams A-G, Kamwininaang SK, Abizari A-R. The effect of maternal and child factors on stunting, wasting and underweight among preschool children in Northern Ghana. BMC Nutr. 2017;3:31.

52. Lukusa Kazadi A, Ngiyulu RM, Gini-Ehungu JL, Mbuyi-Muamba JM, Aloni MN Factors associated with growth retardation in children suffering from sickle cell anemia: first report from central Africa. Anemia. 2017;2017:7916348.

\section{Publisher's Note}

Springer Nature remains neutral with regard to jurisdictional claims in published maps and institutional affiliations. 